\title{
Influence of Stem Diameter on Fiber Diameter and the Mechanical Properties of Technical Flax Fibers from Linseed Flax
}

\author{
Mercedes Alcock ${ }^{1}$, Shabbir Ahmed ${ }^{2}$, Shawna DuCharme ${ }^{1}$ and Chad A. Ulven ${ }^{2, *}$ \\ 1 Composites Innovation Centre, Winnipeg, MB R3P 0Z6, Canada; MAlcock@compositesinnovation.ca (M.A.); \\ sducharme@compositesinnovation.ca (S.D.) \\ 2 Department of Mechanical Engineering, North Dakota State University, Fargo, ND 58105, USA; \\ shabbir.ahmed@ndus.edu \\ * Correspondence: chad.ulven@ndsu.edu; Tel.: +1-701-231-5641
}

Received: 15 December 2017; Accepted: 24 January 2018; Published: 5 February 2018

\begin{abstract}
The continued search for sustainable and eco-friendly materials has led to the integration of bio-fibers, such as flax fiber, as reinforcement in composite materials; however, a wide variation in their diameters and mechanical properties poses a considerable challenge for their incorporation in load bearing and structural bio-composite materials. In this paper, a rigorous experimental investigation was performed using two varieties of linseed flax from two growing locations to determine if the variations observed in ultimate tensile strength, Young's modulus, failure strain and diameter could be attributed to the diameters of the stems that produced the fibers. Tests were performed in two different facilities and the results were compared and analyzed using Welch's $t$-tests. Results showed that samples which differed by stem diameter had statistically significant positive correlation with fiber diameter and negative correlation with tensile strength. No correlations for tensile strength, Young's modulus or fiber diameter were found in samples with the same stem diameter range that were grown in different locations or were of different varieties, that is the effect of location and variety is not statistically significant. Failure strain did not show any statistical significance with respect to differences in stem diameter and only showed one statistically significant result between both facilities for one of the two growing location comparisons.
\end{abstract}

Keywords: flax fiber; technical fiber; diameter variation; statistical analysis; Welch's $t$-test; tensile strength; Young's modulus; strain

\section{Introduction}

\subsection{Background}

The term bio-composite is of recent origin, and this type of composite material is capable of addressing recent environmental issues such as the non-recyclability of petroleum-based composites and the need to dispose of them in landfills [1]. In bio-composites, natural fibers such as flax, hemp, ramie, etc. are used as a reinforcing element and bio-polymers derived from cellulose, starch, lactic acid, etc. are used as the matrix element [2]. In addition to recyclability, bio-composites offer some other benefits; they are light weight, nontoxic and nonabrasive. The property of being lighter weight results from the lower density of natural fibers; the density of flax fibers ranges around $1.42-1.5 \mathrm{~g} / \mathrm{cm}^{3}$ whereas glass fibers can have densities around $2.5 \mathrm{~g} / \mathrm{cm}^{3}$ [3].

Flax fiber bundles are located towards the exterior part of the flax stem and reside in between the cortex and the phloem tissue. Each stem contains approximately 20-50 fiber bundles or fascicles and each bundle is comprised of around 10-30 elementary fibers [4-6]. The typical diameter of an 
elementary fiber varies from 10-20 $\mu \mathrm{m}$. Elementary fibers can remain adhered together by pectins and other encrusting natural polymers after extraction and these adhered units are referred to as a technical fiber [7-9]. Typically, the diameter of technical fibers vary between 35-150 $\mu \mathrm{m}$ [10].

Elementary fibers are essentially multinucleate single elongated sclerenchyma cells [11]. These elementary fibers are not uniform monofilaments like glass or carbon fibers, rather they are layered structures and a composite in themselves [12]. Elementary fibers contain substructures called microfibrils which are composed of highly aligned crystalline cellulose interspersed with amorphous cellulose. Microfibrils run parallel to each other and wind helically around the cell. The angle they take is referred to as the microfibril angle (MFA) [13].

The mechanical performance of a composite is a function of the mechanical performance, volume, and orientation of its constituents [9]. Knowing this information, composite parts using synthetic fibers can be designed for specific loading conditions and have an expectation of meeting performance requirements from part to part. However, for bast fibers, reported values for the tensile strength and Young's modulus can vary widely depending on the sample or source of the data [14-17]. Other factors such as poor interfacial adhesion and fiber defects further reduce the actual composite tensile strength that is achievable in comparison to the tensile strength observed by fibers themselves [9]. Composite manufacturers that are attempting to design structural components with bast fibers are forced to design with worst case scenarios resulting from uncertainty in mechanical properties of bast fiber [18] as well as the batch to batch variation [19]. Designing with the worst-case scenario can limit the adoption of bast fibers as reinforcement in load bearing structures [20]. For these reasons, research regarding quantifying, understanding, and predicting the mechanical performance of bast fibers has become important to composite manufacturers.

\subsection{Purpose of Study}

It has been shown that the mechanical properties of fibers improve with decreasing MFA and increasing cellulose content of the cell walls [14,21]. On the other hand, fiber and plant morphology can be affected by lodging and environmental stresses caused by seasonal changes $[8,22,23]$. Additionally, the location of fiber within the stem has influence on the fiber morphology, mechanical, and biochemical properties. As for example, the fibers located at the middle of the stem possess the best mechanical performance [24-27]. While these studies have provided essential information on the structure of flax and its variability, the industrial application of the work has been limited. However, a few recent studies have focused on determining the effect of fiber performance from agronomical factors [28], which are controllable by farmers. The ability to predict fiber performance while in the stem $[23,29,30]$, may alleviate the need to invest in fiber processing before a value can be determined. These types of connections are important to advance industrial development of natural fibers. This study attempts to further those connections by evaluating the effect of stem diameter on the technical fiber mechanical properties of linseed flax.

According to Bourmaud et al. [28], the seeding density of linen flax can influence the average stem diameter. As for example, a seeding rate of 1110 plants $/ \mathrm{m}^{2}$ produced a stem diameter of $1.87 \pm 0.34 \mathrm{~mm}$ and a seeding rate of 2190 plants $/ \mathrm{m}^{2}$ produced a stem diameter of $0.91 \pm 0.2 \mathrm{~mm}$. They determined that sowing density had a low impact on the fiber's mechanical properties until a critical value, which could be a result of fiber structure, chemical composition and/or a decrease in nutrients at higher seeding rates. A seeding rate of 1800 seeds $/ \mathrm{m}^{2}$ was recommended as optimal based on fiber yield, mechanical performance and plant stability.

While Bourmaud et al. [28] investigated the plant densities ranging from 1110 plants $/ \mathrm{m}^{2}$ to 2190 plants $/ \mathrm{m}^{2}$, the plant densities for linseed flax (grown for seed) are significantly smaller. The Flax Council of Canada [31] recommends that for unirrigated fields, plant densities should be no less than 300 plants $/ \mathrm{m}^{2}$ for optimum seed yield, and that densities greater than 400 plants $/ \mathrm{m}^{2}$ can increase the chance of lodging and may not show increase in yield. 
In a work conducted by Bell [32], which related maturity of linseed flax to tensile strength, a correlation was identified for linseed flax plants linking stem diameter and fiber tensile strength. Smaller stems produced superior fibers with higher strengths compared to their larger stem counterparts. It was hypothesized that the small stalk flax plants may need to rely on the constituent fibers for reinforcement to withstand bending forces, whereas large stalk plants would be able to capitalize on their stiffer geometry (thicker stems and corresponding greater cross-sectional area).

\section{Experimental Section}

\subsection{Experiment Overview}

To demonstrate that stem diameter correlates with the extracted fibers' performance and that fibers from small stems outperform fibers extracted from large stems, single fiber tensile testing was selected as a test method to provide ultimate tensile strength, Young's modulus, failure strain and fiber diameter values for the samples. Based on the literature found studying the relationship of MFA, chemical composition, and the mechanical properties of flax fiber $[14,21]$, it was anticipated that ultimate tensile strength and Young's modulus would be higher in fibers extracted from small stems. Bourmaud et al. $[21,28]$ found that strain at break values did not typically correlate with MFA and that only in the highest seeding rates a statistically significant difference was found. Therefore, it was anticipated that failure strain would not be statistically significant in the current study involving linseed flax. Some research exists which correlates fiber diameters to stem diameters in linen flax grown for fiber production [28,33]. However, no research was found providing insight into an expected relationship of the diameter of technical fiber after extraction and the corresponding diameter of the stem for linseed flax grown for seed production. Testing was performed at two separate facilities as part of a research partnership between the Composites Innovation Centre, Winnipeg, Manitoba, Canada (CIC) and North Dakota State University (NDSU), Fargo, North Dakota, United States of America and results were compared and validated. To substantiate the hypotheses, it was expected that the results would be statistically significant in their differences.

While the hypotheses did not include differences arising from varieties or locations as being potential sources of mechanical differences in extracted fibers, it was prudent to evaluate these cases to determine if the differences in performance arising from stem size were outweighed by differences in variety or location. Therefore, this experiment investigated the following permutations of the samples:

- Stems of different diameter ranges with the same variety and grown in the same geographical location;

- Stems from different geographical locations with the same variety and with the same stem diameter range;

- Stems from two different linseed varieties grown in the same geographical location and with the same stem diameter range.

\subsection{Materials}

Flax fibers were provided by the Composites Innovation Center, Winnipeg, Canada. Flax plants of the variety CDC Bethune and Prairie Grande were grown in two different locations (Melita and Arborg) in Manitoba, Canada in 2015. CDC Bethune is a linseed flax variety with good lodging resistance and resistance to fusarium wilt that was developed in 1998 by the Crop Development Centre, University of Saskatchewan, Saskatoon, Saskatchewan, Canada and is still commercially available and commonly grown in North America [34]. Prairie Grande is a linseed flax that was released in 2007, by Agriculture and Agrifood, Manitoba, Canada. Better disease resistance properties have made it a useful cultivar in Canada and North American countries [34]. Flax stems were harvested using a flax puller which laid the entire flax stem, including roots, into windrows. The stems were collected before they were able to ret in the field. The visible dirt line was used as the reference mark and the diameter was measured $15 \mathrm{~cm}$ above the dirt line. Stems were sorted into three categories: small (less than 
$1.5 \mathrm{~mm}$ ), medium $(1.5 \mathrm{~mm}$ to $1.65 \mathrm{~mm}$ ) and large (greater than $1.65 \mathrm{~mm}$ ). Only the small and large diameter stems were used for testing. These ranges were selected to ensure that a meaningful amount of stems from each sample location fell in the medium range such that the small and large categories would be distinct from each other, but not so different that the small and large diameter categories only represented the extremities of size. Combining these different criteria (stem diameter, location of growth, and variety), six distinct samples were prepared: Arborg Large, Arborg Small, Melita Large, Melita Small, Prairie Grande Large (PG Large), and Prairie Grande Small (PG Small). Table 1 shows this categorization more specifically as well as the percentage (by stem count) of material that fell into the medium diameter categories.

Table 1. Formation of the six flax samples.

\begin{tabular}{cccccc}
\hline Sample Name & Location & Variety & Stem Size (mm) & \% Stems by Count & $\begin{array}{c}\text { \% Medium } \\
\text { Stems by Count }\end{array}$ \\
\hline Arborg Large & Arborg & Bethune & $>1.65$ & $42 \%$ & $16 \%$ \\
Arborg Small & Arborg & Bethune & $<1.50$ & $42 \%$ & $7 \%$ \\
\hline Melita Large & Melita & Bethune & $>1.65$ & $63 \%$ & $30 \%$ \\
Melita Small & Melita & Bethune & $<1.50$ & $36 \%$ & $14 \%$ \\
\hline PG Large & Melita & Prairie Grande & $>1.65$ & $50 \%$ & \multirow{2}{*}{ PG Small } \\
\hline
\end{tabular}

To assist in decortication as well as to reduce inter-fiber bonding materials such as pectin, the samples were subjected to an enzymatic retting process. Prior to enzyme retting, stems were deseeded and then gently crimped using a wooden tool to allow the enzyme solution to penetrate easily into the stems; this facilitated proper enzyme retting.

Stems were enzyme retted using a pectinase enzyme (Bioprep 3000L), EDTA and buffer solution. The enzyme concentration was 5\%. The stems were soaked in the enzyme solution for $5 \mathrm{~min}$ and then removed from the soaking tub. The unrinsed stems were placed in sealed bags and incubated at $55{ }^{\circ} \mathrm{C}$ for two hours. Next the stems were soaked in an EDTA and buffer solution for $30 \mathrm{~min}$ and incubated again at $55^{\circ} \mathrm{C}$ for $22 \mathrm{~h}$. The stems were then rinsed thoroughly with tap water to remove the remaining enzyme/EDTA solution. The stems were spread out flat to dry in a fume hood at ambient temperature for $12 \mathrm{~h}$. Next, the fibers were manually decorticated from the stem with the aid of the same wooden crimping tool used in the pre-crimp step. Following the enzyme retting and decortication steps, the fiber material from each sample was divided and provided to each facility for testing. Each facility used their own specimen preparation procedures to select and prepare fibers for their respective test methods.

\subsection{Methods}

At North Dakota State University, the diameter of each fiber was measured using a Zeiss Axiovert 40 MAT inverted optical microscope with an attached camera of Progress C10 Plus (Carl Zeiss Light Microscopy, Jena, Germany). The diameter of each fiber specimen was measured in three different locations and then averaged for each specimen. A circular cross-section was assumed and the average diameter was used for calculating the area. The effect of lumen was neglected [24-26]. The cross-section of these technical fibers is not circular, but rather more of an elliptical shape. Thomason et al. [35] maintained that the assumption of a circular cross-section overestimates the true cross-section of flax fibers and proposed a common scale factor in order to correct the circular area to a more elliptical shape. In this study, a factor of 2, as recommended by Thomason et al. [35], was used in order to correct for the circular area assumptions.

For tensile testing, a gauge length of $20 \mathrm{~mm}$ was selected for proper handling of the fiber specimens. A Deben micro-tensile tester (Deben UK Ltd., Suffolk, UK), which is more generally used for in-situ observation of a specimen under tension in an electron microscope, was selected for the testing. 
The maximum load that can be measured with the machine is $180 \mathrm{~N}$ with a load cell linearity of $1.5 \%$. Force and position resolution of the machine were $0.001 \mathrm{~N}$ and $0.0001 \mathrm{~mm}$ respectively. Displacement rate of the crosshead was selected to be $0.75 \mathrm{~mm} / \mathrm{min}$, resulting in a strain rate of $0.000625 \mathrm{~s}^{-1}$. ASTM standard D3822 was followed for determining the mechanical properties of the fibers. The fibers were mounted using clamping forces as shown in Figure 1.

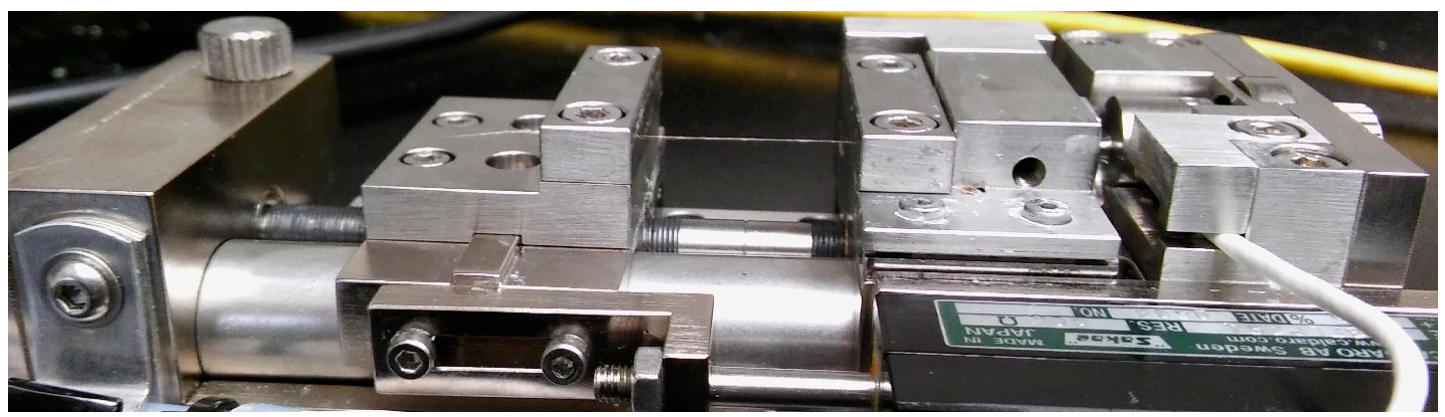

Figure 1. Clamped fiber in North Dakota State University (NDSU)'s Deben micro-tensile tester.

At least 50 fibers were tested from each of the six samples listed in Table 1. Specimens that did not break in the gauge length were invalidated. All the testing of NDSU flax fibers was performed in a temperature and humidity controlled laboratory $\left(21^{\circ} \mathrm{C} \pm 1{ }^{\circ} \mathrm{C}\right.$ and $\left.18 \% \mathrm{RH} \pm 3 \%\right)$.

The CIC used a combined diameter and tensile measurement system. Tabs were used at either end of the gauge length and fibers were mounted to the tabs using a high viscosity, UV curing, acrylated urethane (Dymax 3193) as the fixative. The diameter was measured using a laser scanner LSM6000-500s (Mitutoyo, Kanagawa, Japan) which is attached to a FDAS760 specimen holder (Dia-Stron Limited, Andover, UK). A portion of the laser beam is interrupted by the fiber and based on the measurement of the shadow cast, a detector interprets the size of the fiber. The fiber is rotated $360^{\circ}$ around its axis to capture numerous 2D measurements. Figure 2a shows a sample measurement of the fiber diameter by the rotational laser scanner. In Figure $2 \mathrm{a}$ the minimum fiber diameter was approximately $35 \mu \mathrm{m}$ and the maximum fiber diameter was approximately $85 \mu \mathrm{m}$. Figure $2 \mathrm{~b}$ shows the overall set-up of the laser scanner.

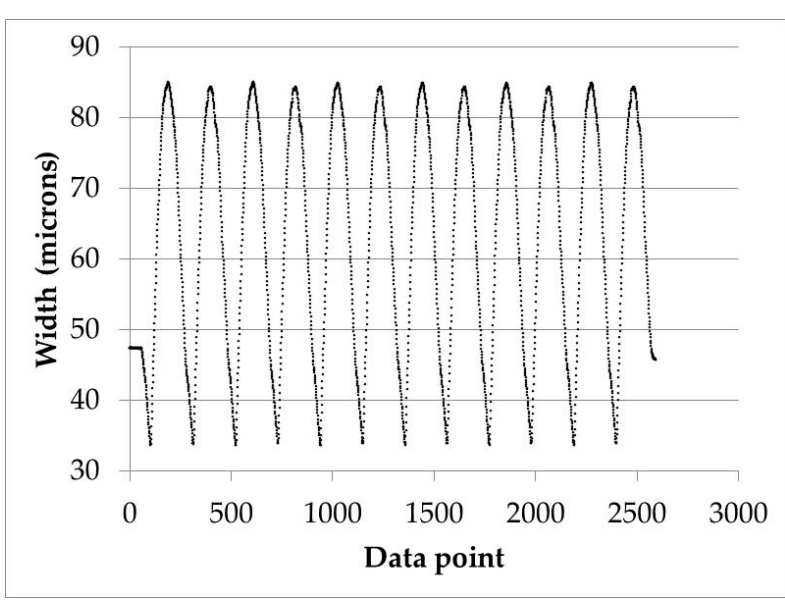

(a)

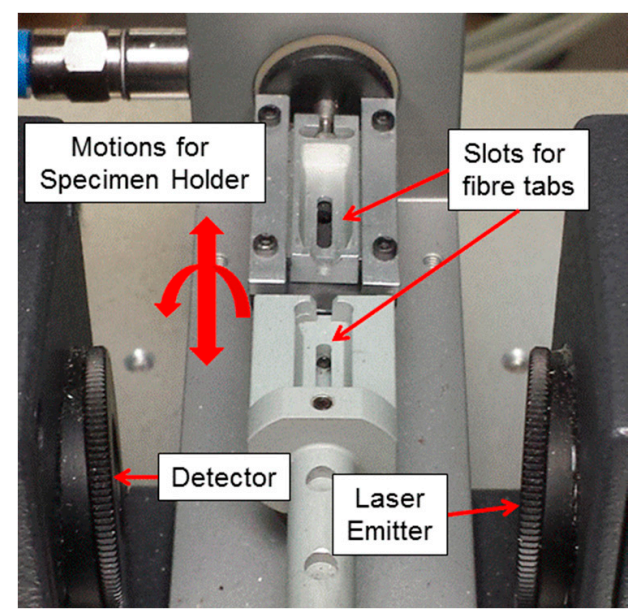

(b)

Figure 2. Output from the laser scanner showing the variation of widths during 6 rotations (a). Equipment setup showing the laser emitter, detector, and moving sample holder (b).

The measurements from the rotational laser scanner can be used to determine the minimum and maximum diameter of the fiber which allows the determination of cross-sectional area, assuming an 
elliptical shape. The measurement range of the laser for cross-sectional diameter is 5-2000 $\mu \mathrm{m}$, sufficient for the 35-150 $\mu \mathrm{m}$ range in the samples. For comparison purposes with NDSU data, the calculated cross-sectional area was converted into a single, equivalent (circular) diameter for each of the fibers.

For tensile testing a gauge length of $4 \mathrm{~mm}$ was selected. The smaller gauge attempted to control the failure mode of the technical fiber to intra-fiber breakage instead of inter-fiber shearing. The CIC system consisted of a screw based linear actuator and load cell to produce and measure an applied load, respectively. The combination is sold as a LEX820 tensile tester (Dia-Stron, Andover, UK). The equipment has a load cell capacity of $10 \mathrm{~N}$ with a load cell linearity of $0.08 \%$. The speed range for the tensile tester is $0.01-60 \mathrm{~mm} / \mathrm{min}$. The positional accuracy is $50 \mu \mathrm{m}$ with a displacement resolution of $1 \mu \mathrm{m}$ and the maximum elongation is $50 \mathrm{~mm}$.

For CIC specimens with the shorter gauge length (target of $4 \mathrm{~mm}$ ) strain can be more heavily influenced by machine compliance where relatively small displacements in the apparatus, separate from the fiber displacement (such as deformation of the adhesive used to mount the specimens), represent a larger portion of the whole displacement than they would if the gauge length was longer. CIC employed a system compliance correction to its strain data which was determined using a method found in ASTM C1557 [36]. In addition, curves that displayed a toe region indicative of slack, alignment, or seating of the specimen and not related to the specimen properties were corrected by using a trend line through the linear portion of the strain curve and adjusting for the corrected zero point.

The CIC tested fibers for each of the six samples listed in Table 1 using a strain rate of $0.00165 \mathrm{~s}^{-1}$. Specimens that did not break in the gauge length or had unclear dimensional data were invalidated. All the testing of $\mathrm{CIC}$ flax fibers was performed in a temperature controlled laboratory $\left(23^{\circ} \mathrm{C} \pm 1{ }^{\circ} \mathrm{C}\right.$ and $50 \% \mathrm{RH} \pm 3 \%$ ).

\section{Results and Discussion}

\subsection{Variation in Ultimate Tensile Strength}

Due to the differences in test method between CIC and NDSU, particularly differences in gauge length, mounting methods, and humidity conditions [26], it was not expected that the ultimate tensile strength found for each sample would be the same for both facilities; however, the relative results between samples tested at different facilities would be comparable. The tensile strength results from NDSU and CIC have been compiled in Table 2.

Table 2. Ultimate tensile strength of the six samples of flax fibers from NDSU and composites innovation centre (CIC).

\begin{tabular}{ccccc}
\hline \multirow{2}{*}{ Sample } & \multicolumn{2}{c}{ NDSU } & \multicolumn{2}{c}{ CIC } \\
\cline { 2 - 5 } & $\begin{array}{c}\text { Number } \\
\text { of Records }\end{array}$ & $\begin{array}{c}\text { Mean and Standard } \\
\text { Deviation (MPa) }\end{array}$ & $\begin{array}{c}\text { Number } \\
\text { of Records }\end{array}$ & $\begin{array}{c}\text { Mean and Standard } \\
\text { Deviation (MPa) }\end{array}$ \\
\hline Arborg Large & 45 & $641 \pm 667$ & 48 & $836 \pm 272$ \\
Arborg Small & 45 & $890 \pm 829$ & 45 & $857 \pm 261$ \\
Melita Large & 45 & $427 \pm 390$ & 43 & $718 \pm 272$ \\
Melita Small & 48 & $723 \pm 576$ & 41 & $873 \pm 281$ \\
PG Large & 49 & $521 \pm 432$ & 50 & $745 \pm 290$ \\
PG Small & 49 & $771 \pm 545$ & 43 & $874 \pm 232$ \\
\hline
\end{tabular}

Representing the data as box and whisker charts, it can be seen that although the standard deviations are high for NDSU's samples, the quartile comparisons indicate a visual difference in the ranges between small and large stem samples (Figure 3). For comparison, CIC's results are graphed in Figure 4. For all box and whisker plots in this study, solid black dots represent the mean. Outlined dots are individual data points. Whiskers represent the span of data points that fall within the interquartile 
range (1.5IQR). Red dots extending past the whiskers represent values exceeding 1.5IQR. Due to the relatively small data sets, no values were removed as outliers.

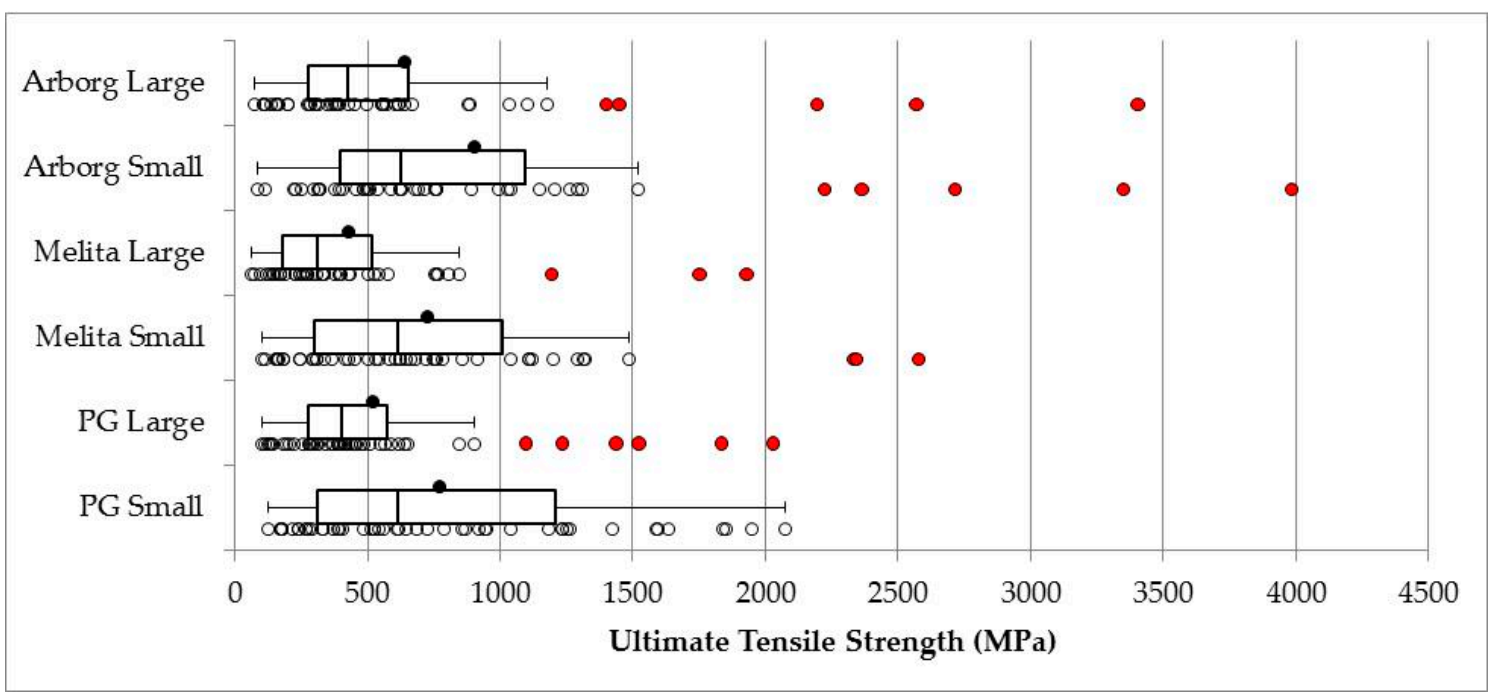

Figure 3. Distribution of tensile strengths of NDSU samples.

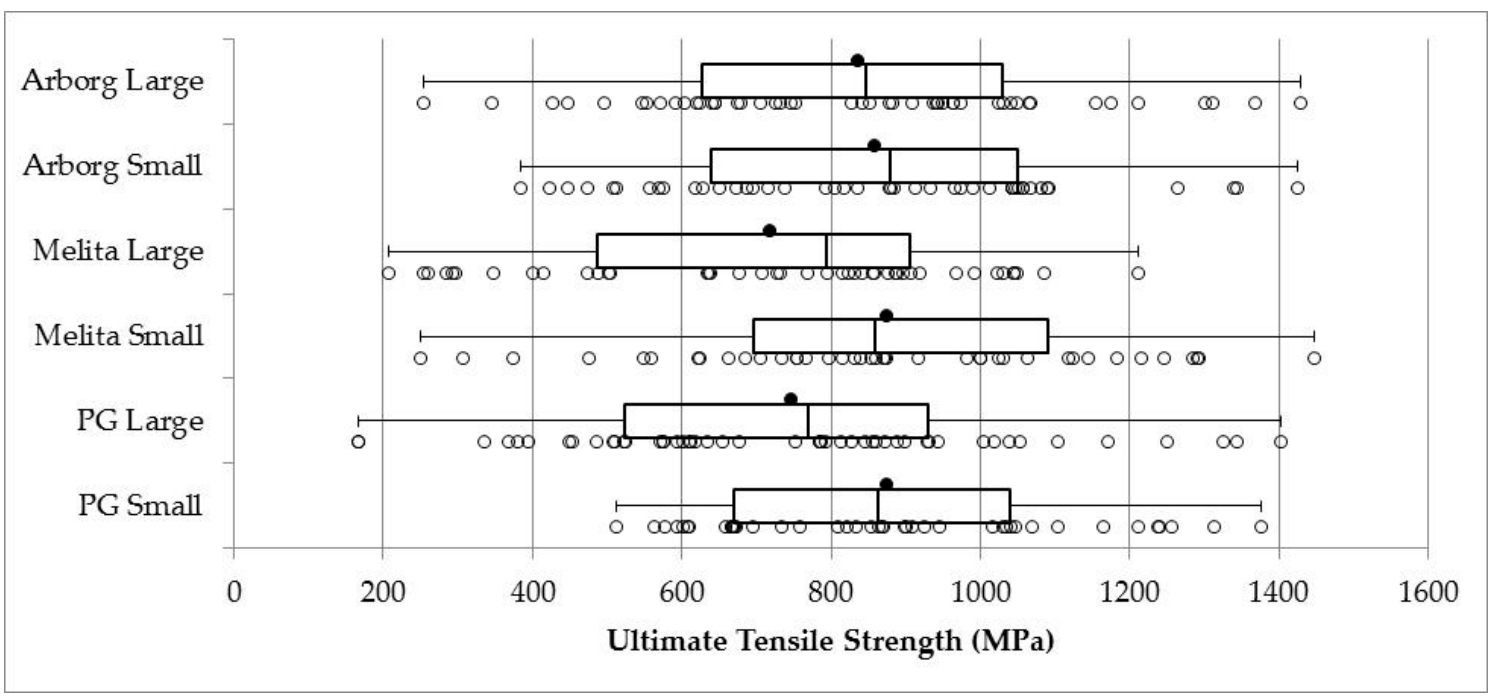

Figure 4. Distribution of tensile strengths of CIC samples.

Comparing the mean values from Table 2 and the quartile information from Figures 3 and 4, the trend can be seen within the results from each facility that the large stem samples have a lower tensile strength performance in comparison to their small stem counterparts. For NDSU, the large stem materials saw a reduction in tensile strength of $28 \%$ to $41 \%$, which is a substantial reduction in performance for a reinforcement material in a composite application.

To determine if this trend was statistically significant, a Welch's $t$-test was selected. Welch's $t$-test was selected over other methods of comparison because it does not assume equal variances exist between samples and is suitable when the number of records is not equal between the sample groups.

Two hypotheses were defined. The null hypothesis, denoted $\mathrm{H}_{0}$, represents the hypothesis that will be accepted unless the data provides convincing evidence that it is false. The alternative hypothesis or research hypothesis, denoted $\mathrm{H}_{\mathrm{a}}$, represents the hypothesis that will be accepted only if the data provides convincing evidence of its truth. 
For technical flax fibers in this study, to prove that the samples from small stems produced fibers with higher ultimate tensile strengths than their large stem counterparts, the following null and right-tailed hypotheses were formed:

$$
\begin{aligned}
& \mathrm{H}_{0}: \sigma_{1}=\sigma_{2} \\
& \mathrm{H}_{\mathrm{a}}: \sigma_{1}>\sigma_{2}
\end{aligned}
$$

where,

$$
\begin{aligned}
& \sigma_{1}=\text { ultimate strength of the small stem sample } \\
& \sigma_{2}=\text { ultimate strength of the large stem sample }
\end{aligned}
$$

The formula for calculating $t_{\text {value }}$ is as follows:

$$
t_{\text {value }}=\frac{d_{1}-d_{2}}{\sqrt{\frac{s_{1}^{2}}{n_{1}}+\frac{s_{2}^{2}}{n_{2}}}}
$$

where,

$$
\begin{gathered}
s_{1}=\text { standard deviation of the small stem sample } \\
s_{2}=\text { standard deviation of the large stem sample } \\
n_{1}=\text { sample size of the small stem sample } \\
n_{2}=\text { sample size of the large stem sample }
\end{gathered}
$$

For Welch's $t$-test the degree of freedom was calculated using the Welch-Satterthwaite equation for pooled degrees of freedom as follows:

$$
v_{\mathrm{f}}=\frac{\left(\frac{s_{1}^{2}}{n_{1}}+\frac{s_{2}^{2}}{n_{2}}\right)^{2}}{\frac{s_{1}^{4}}{v_{1} n_{1}{ }^{2}}+\frac{s_{2}^{4}}{v_{2} n_{2}{ }^{2}}}
$$

where,

$$
\begin{aligned}
& v_{1}=n_{1}-1 \\
& v_{2}=n_{2}-1
\end{aligned}
$$

For a $>95 \%$ and $>99.9 \%$ probability that the alternate hypothesis is true, the corresponding significance level or $p$-value would be $<0.05$ and $<0.001$, respectively.

In addition to the hypothesis that the small stem samples produced fibers with a higher tensile strength than their larger stem counterparts, it was prudent to evaluate whether location or varietal differences also resulted in any statistical significant differences as a comparison. Using the Welch's $t$-test described above, the following two-sided hypotheses were also tested:

- There was a difference in tensile strength between large stem samples of the same variety that were grown in different locations;

- There was a difference in tensile strength between small stem samples of the same variety that were grown in different locations;

- There was a difference in tensile strength between large stem samples of the different varieties that were grown in the same location;

- There was a difference in tensile strength between small stem samples of the different varieties that were grown in the same location.

Table 3 includes the results of Welch's $t$-test, showing the range found for the $p$-value for each of the hypotheses. 
Table 3. $p$-value results for ultimate strength comparison.

\begin{tabular}{|c|c|c|c|c|c|}
\hline Comparison & Alternate Hypothesis $\left(\mathrm{H}_{\mathrm{a}}\right)$ & $\begin{array}{l}\text { Samples } \\
\text { Compared }\end{array}$ & $\begin{array}{c}p \text {-Value } \\
\text { NDSU Data }\end{array}$ & $\begin{array}{l}p \text {-Value } \\
\text { CIC Data }\end{array}$ & $\begin{array}{l}\text { Hypothesis } \\
\text { Results }\end{array}$ \\
\hline \multirow{3}{*}{$\begin{array}{l}\text { Small Stems vs. } \\
\text { Large Stems }\end{array}$} & Arborg Small > Arborg Large & $\begin{array}{l}\text { Arborg Large } \\
\text { Arborg Small }\end{array}$ & $>=0.05$ & $>=0.05$ & $\mathrm{H}_{\mathrm{a}}$ rejected \\
\hline & Melita Small > Melita Large & $\begin{array}{l}\text { Melita Large } \\
\text { Melita Small }\end{array}$ & $<0.05$ & $<0.05$ & $\begin{array}{c}>95 \% \text { probability } \\
\mathrm{H}_{\mathrm{a}} \text { accepted }\end{array}$ \\
\hline & PG Small > PG Large & $\begin{array}{l}\text { PG Large } \\
\text { PG Small }\end{array}$ & $<0.05$ & $<0.05$ & $\begin{array}{c}>95 \% \text { probability } \\
\mathrm{H}_{\mathrm{a}} \text { accepted }\end{array}$ \\
\hline Different & \multirow{2}{*}{ Melita $\neq$ Arborg } & $\begin{array}{l}\text { Melita Large } \\
\text { Arborg Large }\end{array}$ & $>=0.05$ & $<0.05$ & Inconclusive \\
\hline $\begin{array}{l}\text { Locations, } \\
\text { Same Variety }\end{array}$ & & $\begin{array}{l}\text { Melita Small } \\
\text { Arborg Small }\end{array}$ & $>=0.05$ & $>=0.05$ & $\mathrm{H}_{\mathrm{a}}$ rejected \\
\hline \multirow{2}{*}{$\begin{array}{c}\text { Different } \\
\text { Variety, Same } \\
\text { Location }\end{array}$} & \multirow{2}{*}{ Bethune $\neq$ Prairie Grande } & $\begin{array}{l}\text { Melita Large } \\
\text { PG Large }\end{array}$ & $>=0.05$ & $>=0.05$ & $\mathrm{H}_{\mathrm{a}}$ rejected \\
\hline & & $\begin{array}{l}\text { Melita Small } \\
\text { PG Small }\end{array}$ & $>=0.05$ & $>=0.05$ & $\mathrm{H}_{\mathrm{a}}$ rejected \\
\hline
\end{tabular}

The results of the statistical comparison for large and small stem tensile strength relationships show that, among the 3 comparisons, two were found to have a $>95 \%$ probability that the difference between the small and large stem performance was statistically significant. In the case of the Arborg sample, both CIC and NDSU found no statistical significance, but mean values and median values were still higher for both facilities' small stems as compared to the large. In comparison, of the 4 scenarios tested regarding variety and location, the alternate hypothesis was rejected by both facilities in 3 cases and in one case a significance was found at only one facility.

\subsection{Variation in Young's Modulus}

Similar to the ultimate tensile strength testing, it was not expected that NDSU's and CIC's modulus values would match between facilities, but relative trends could be compared. NDSU's and CIC's Young's modulus results are included in Table 4.

Table 4. NDSU and CIC's Young's modulus (GPa) results for the six samples of flax fibers.

\begin{tabular}{ccccc}
\hline \multirow{2}{*}{ Sample } & \multicolumn{2}{c}{ NDSU } & \multicolumn{2}{c}{ CIC } \\
\cline { 2 - 5 } & Number of & $\begin{array}{c}\text { Mean and Standard } \\
\text { Deviation (GPa) }\end{array}$ & $\begin{array}{c}\text { Number of } \\
\text { Records }\end{array}$ & $\begin{array}{c}\text { Mean and Standard } \\
\text { Deviation (GPa) }\end{array}$ \\
\hline Arborg Large & 45 & $55 \pm 38$ & 48 & $37 \pm 10$ \\
Arborg Small & 44 & $82 \pm 66$ & 45 & $38 \pm 10$ \\
Melita Large & 45 & $56 \pm 31$ & 43 & $40 \pm 10$ \\
Melita Small & 48 & $78 \pm 48$ & 51 & $34 \pm 11$ \\
PG Large & 49 & $57 \pm 38$ & 43 & $39 \pm 9$ \\
PG Small & 49 & $83 \pm 45$ & & \\
\hline
\end{tabular}

Plotting the results using box and whisker graphs (Figures 5 and 6, respectively) showed that small stem samples had consistently higher medians and larger quartile ranges than their large stem counterparts for NDSU results. CIC results did not show any noticeable, visual differences in the plots for size, location or varietal differences. 


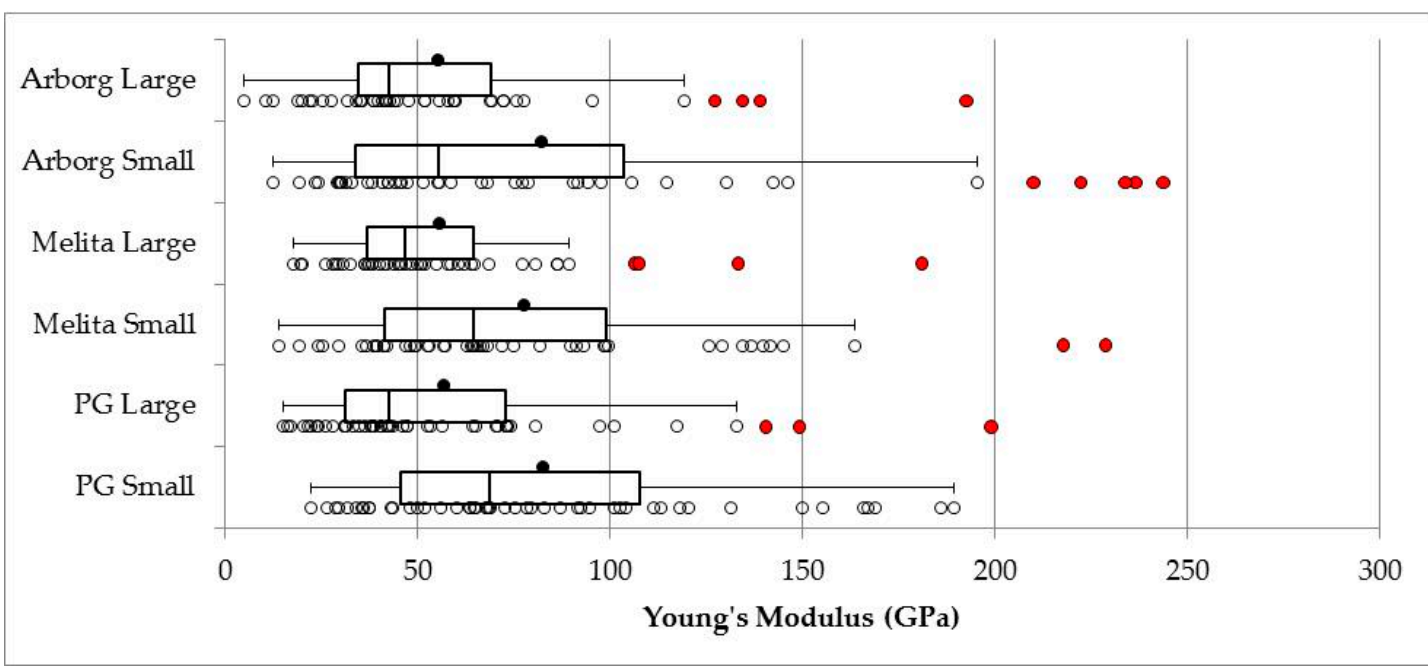

Figure 5. Distribution of Young's modulus results from NDSU.

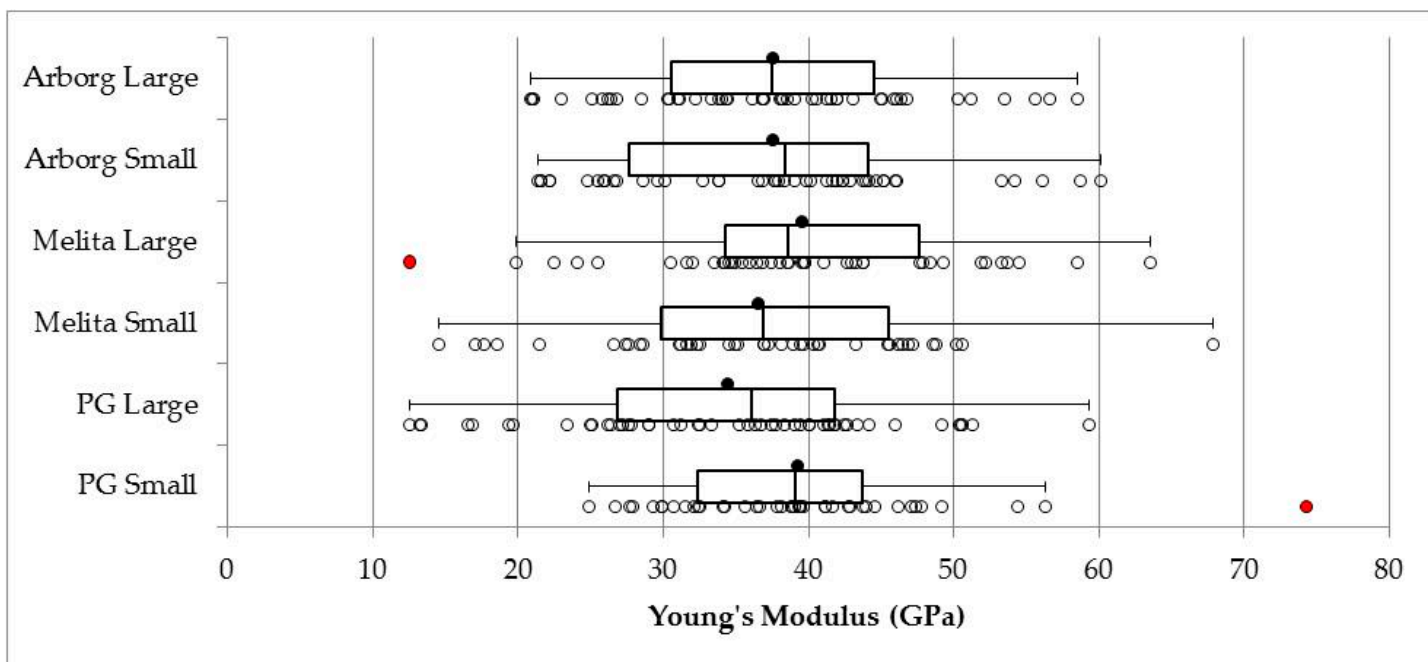

Figure 6. Distribution of Young's modulus results from CIC.

As performed in previous sections, a Welch's $t$-test process was conducted. As the hypothesis being tested was that small stem samples would have a higher modulus than large stem samples, a right-tailed test was conducted for that comparison. A two-tailed test was used to compare the results between locations and varieties. The results for both facilities were compiled in Table 5 .

Table 5. $p$-value results for Young's modulus comparison.

\begin{tabular}{cccccc}
\hline Comparison & Alternate Hypothesis $\left(\mathrm{H}_{\mathbf{a}}\right)$ & $\begin{array}{c}\text { Samples } \\
\text { Compared }\end{array}$ & $\begin{array}{c}p \text {-Value } \\
\text { NDSU Data }\end{array}$ & $\begin{array}{c}p \text {-Value CIC } \\
\text { Data }\end{array}$ & $\begin{array}{c}\text { Hypothesis } \\
\text { Results }\end{array}$ \\
\hline Arborg Small $>$ Arborg Large & $\begin{array}{c}\text { Arborg Large } \\
\text { Arborg Small } \\
\text { Melita Large }\end{array}$ & $<0.05$ & $>=0.05$ & Inconclusive \\
$\begin{array}{c}\text { Small Stems vs. } \\
\text { Large Stems }\end{array}$ & Melita Small $>$ Melita Large & $\begin{array}{c}\text { Melita Small } \\
\text { PG Large } \\
\text { PG Small }\end{array}$ & $<6.05$ & $>=0.05$ & $\begin{array}{c}\text { Inconclusive } \\
>95 \% \text { probability } \\
\mathrm{H}_{\mathrm{a}} \text { accepted }\end{array}$ \\
\hline
\end{tabular}


Table 5. Cont.

\begin{tabular}{cccccc}
\hline Comparison & Alternate Hypothesis $\left(\mathrm{H}_{\mathbf{a}}\right)$ & $\begin{array}{c}\text { Samples } \\
\text { Compared }\end{array}$ & $\begin{array}{c}p \text {-Value } \\
\text { NDSU Data }\end{array}$ & $\begin{array}{c}p \text {-Value CIC } \\
\text { Data }\end{array}$ & $\begin{array}{c}\text { Hypothesis } \\
\text { Results }\end{array}$ \\
\hline $\begin{array}{c}\text { Different } \\
\text { Locations, }\end{array}$ & Melita $\neq$ Arborg & $\begin{array}{c}\text { Melita Large } \\
\text { Arborg Large } \\
\text { Melita Small } \\
\text { Arborg Small }\end{array}$ & $>=0.05$ & $>=0.05$ & $\mathrm{H}_{\mathrm{a}}$ rejected \\
\hline $\begin{array}{c}\text { Different } \\
\text { Variety, Same } \\
\text { Location }\end{array}$ & Bethune $\neq$ Prairie Grande & $\begin{array}{c}\text { Melita Large } \\
\text { PG Large } \\
\text { Melita Small } \\
\text { PG Small }\end{array}$ & $>=0.05$ & $>=0.05$ & $\mathrm{H}_{\mathrm{a}}$ rejected \\
\hline
\end{tabular}

Unlike the strength results, the Young's modulus results do not show a strong statistical trend at both facilities for stem size, location, or variety. The NDSU data suggested that there is a trend that the small stem samples are statistically different than their large stem counterparts. This relationship was substantiated by CIC's data in only one case, PG Small vs. PG Large.

\subsection{Variation in Failure Strain}

For the NDSU specimens, the gauge length of the fiber (target of $20 \mathrm{~mm}$ ) can be measured from the grip separation with reasonable accuracy. The extension of the fiber was measured from the crosshead displacement given that the fibers were straight and taut and that the resolution of the Deben micro-tensile tester was sufficient. Results of the NDSU testing are shown in Table 6.

Table 6. NDSU and CIC failure strain (\%) results for the six samples of flax fibers.

\begin{tabular}{ccccc}
\hline & \multicolumn{2}{c}{ NDSU } & CIC \\
\cline { 2 - 5 } Sample & $\begin{array}{c}\text { Number of } \\
\text { Records }\end{array}$ & $\begin{array}{c}\text { Mean and Standard } \\
\text { Deviation (\%) }\end{array}$ & $\begin{array}{c}\text { Number of } \\
\text { Records }\end{array}$ & $\begin{array}{c}\text { Mean and Standard } \\
\text { Deviation (\%/N) }\end{array}$ \\
\hline Arborg Large & 45 & $1.1 \pm 0.5$ & 48 & $2.4 \pm 0.5$ \\
Arborg Small & 44 & $1.2 \pm 0.5$ & 45 & $2.5 \pm 0.5$ \\
Melita Large & 45 & $0.8 \pm 0.4$ & 43 & $1.9 \pm 0.7$ \\
Melita Small & 48 & $0.9 \pm 0.3$ & 41 & $2.6 \pm 0.6$ \\
PG Large & 49 & $0.9 \pm 0.2$ & 50 & $2.3 \pm 0.5$ \\
PG Small & 49 & $0.9 \pm 0.3$ & 43 & $2.4 \pm 0.6$ \\
\hline
\end{tabular}

For the CIC specimens, the strain was also measured using crosshead displacement and corrected using the system compliance method described in the Methods section above. Results of the CIC testing are shown in Table 6.

As performed on the tensile strength and Young's modulus results, a Welch's $t$-test process was conducted. As there was no significance expected for the results, a directionality of small over large was not used and therefore a two-tailed test was used for the stem comparisons as well as the locations and varieties. The results of the analyses are compiled in Table 7.

Table 7. $p$-value results for failure strain comparison.

\begin{tabular}{|c|c|c|c|c|c|}
\hline Comparison & Alternate Hypothesis $\left(\mathrm{H}_{\mathbf{a}}\right)$ & $\begin{array}{l}\text { Samples } \\
\text { Compared }\end{array}$ & $\begin{array}{c}p \text {-Value } \\
\text { NDSU Data }\end{array}$ & $\begin{array}{l}p \text {-Value } \\
\text { CIC Data }\end{array}$ & $\begin{array}{l}\text { Hypothesis } \\
\text { Results }\end{array}$ \\
\hline \multirow{3}{*}{$\begin{array}{l}\text { Small Stems vs. } \\
\text { Large Stems }\end{array}$} & Arborg Small $\neq$ Arborg Large & $\begin{array}{l}\text { Arborg Large } \\
\text { Arborg Small }\end{array}$ & $>=0.05$ & $>=0.05$ & $\mathrm{H}_{\mathrm{a}}$ rejected \\
\hline & Melita Small $\neq$ Melita Large & $\begin{array}{l}\text { Melita Large } \\
\text { Melita Small }\end{array}$ & $>=0.05$ & $<0.001$ & Inconclusive \\
\hline & PG Small $\neq$ PG Large & $\begin{array}{l}\text { PG Large } \\
\text { PG Small }\end{array}$ & $>=0.05$ & $>=0.05$ & $\mathrm{H}_{\mathrm{a}}$ rejected \\
\hline
\end{tabular}


Table 7. Cont.

\begin{tabular}{|c|c|c|c|c|c|}
\hline Comparison & Alternate Hypothesis $\left(\mathrm{H}_{\mathrm{a}}\right)$ & $\begin{array}{l}\text { Samples } \\
\text { Compared }\end{array}$ & $\begin{array}{c}p \text {-Value } \\
\text { NDSU Data }\end{array}$ & $\begin{array}{l}p \text {-Value } \\
\text { CIC Data }\end{array}$ & $\begin{array}{c}\text { Hypothesis } \\
\text { Results }\end{array}$ \\
\hline $\begin{array}{c}\text { Different } \\
\text { Locations, } \\
\text { Same Variety }\end{array}$ & Melita $\neq$ Arborg & $\begin{array}{l}\text { Melita Large } \\
\text { Arborg Large } \\
\text { Melita Small } \\
\text { Arborg Small }\end{array}$ & $\begin{array}{l}<0.05 \\
<0.001\end{array}$ & $\begin{array}{l}<0.001 \\
>=0.05\end{array}$ & $\begin{array}{c}>95 \% \text { probability } \\
\mathrm{H}_{\mathrm{a}} \text { accepted } \\
\text { Inconclusive }\end{array}$ \\
\hline $\begin{array}{c}\text { Different } \\
\text { Variety, Same } \\
\text { Location }\end{array}$ & Bethune $\neq$ Prairie Grande & $\begin{array}{l}\text { Melita Large } \\
\text { PG Large } \\
\text { Melita Small } \\
\text { PG Small }\end{array}$ & $>=0.05$ & $>=0.05$ & $\begin{array}{l}\text { Inconclusive } \\
\mathrm{H}_{\mathrm{a}} \text { rejected }\end{array}$ \\
\hline
\end{tabular}

No trend in failure strain was found between the two facilities. Only one test case, Melita Large vs. Arborg Large, showed any statistical significance.

\subsection{Variation in Diameter}

The diameters of the fibers were measured as part of the single fiber tensile testing and as the methods used to quantify the diameter and cross-sectional area can account for a substantial amount of the uncertainty of the results, it was prudent to report these results as part of this study. Lefeuvre et al. [19] attempted to quantify variation of uncertainty in fiber property results from different sources. They mentioned that $78 \%$ of the uncertainty in elastic modulus and $93 \%$ of the uncertainty in failure stress results from the measurement of the diameter and the cross-sectional area of the fiber.

Due to the differences in test-specific specimen preparation methods and operators between the two facilities it was not assumed that the same diameter for each sample would be found independent of facility. While absolute results were not compared between facilities, relative results between samples tested at different facilities were compared. Table 8 contains the average diameter results for NDSU and the equivalent diameter results for CIC, where the equivalent diameter is the diameter of the circle with an area equal to the cross-sectional area of the elliptical fiber.

Table 8. Diameter results for the six samples of flax fibers for NDSU and CIC.

\begin{tabular}{ccccc}
\hline \multirow{2}{*}{ Sample } & \multicolumn{2}{c}{ NDSU } & CIC \\
\cline { 2 - 5 } & $\begin{array}{c}\text { Number of } \\
\text { Records }\end{array}$ & $\begin{array}{c}\text { Mean and Standard } \\
\text { Deviation }(\mu \mathrm{m})\end{array}$ & $\begin{array}{c}\text { Number of } \\
\text { Records }\end{array}$ & $\begin{array}{c}\text { Mean and Standard } \\
\text { Deviation }(\mu \mathrm{m})\end{array}$ \\
\hline Arborg large & 50 & $92 \pm 33$ & 48 & $72 \pm 14$ \\
Arborg small & 51 & $62 \pm 25$ & 45 & $63 \pm 15$ \\
Melita large & 50 & $99 \pm 30$ & 43 & $71 \pm 12$ \\
Melita small & 50 & $67 \pm 25$ & 41 & $60 \pm 16$ \\
PG large & 50 & $100 \pm 28$ & 50 & $74 \pm 14$ \\
PG small & 52 & $82 \pm 28$ & 43 & $60 \pm 14$ \\
\hline
\end{tabular}

At both facilities, the samples produced from large stem plants yielded technical fibers that were larger in diameter than those produced from small stem plants. This is consistent with Miller et al. who found that large stems yielded coarser fibers and more elementary fibers per bundle than smaller stems [33].

Dimensional differences can be generated by operator bias during the specimen preparation procedure; however, in this case it is unlikely that both facilities would have independently seen this trend. In addition, fiber diameter differences were not expected and found post-testing, further removing the likelihood that operators were inadvertently fulfilling an expected result.

To determine if the differences seen had a detectable statistical significance, a Welch's $t$-test was again used. As the trend seen in the data suggested that the large stem fibers were larger in 
diameter than the small stem counterparts, the alternate hypotheses used for the stem comparisions was right-tailed. For location and varietal differences, a two-tailed test was used. The results of the comparisons are listed in Table 9.

Table 9. $p$-value results for diameter comparison.

\begin{tabular}{|c|c|c|c|c|c|}
\hline Comparison & Alternate Hypothesis $\left(\mathrm{H}_{\mathrm{a}}\right)$ & $\begin{array}{l}\text { Samples } \\
\text { Compared }\end{array}$ & $\begin{array}{c}p \text {-Value } \\
\text { NDSU Data }\end{array}$ & $\begin{array}{l}p \text {-Value } \\
\text { CIC Data }\end{array}$ & Hypothesis Result \\
\hline \multirow{3}{*}{$\begin{array}{l}\text { Small Stems vs. } \\
\text { Large Stems }\end{array}$} & Arborg Large $>$ Arborg Small & $\begin{array}{l}\text { Arborg Large } \\
\text { Arborg Small }\end{array}$ & $<0.001$ & $<0.05$ & $\begin{array}{c}>95 \% \text { probability } \\
\mathrm{H}_{\mathrm{a}} \text { accepted }\end{array}$ \\
\hline & Melita Large > Melita Small & $\begin{array}{l}\text { Melita Large } \\
\text { Melita Small }\end{array}$ & $<0.001$ & $<0.001$ & $\begin{array}{c}>99.9 \% \text { probability } \\
\mathrm{H}_{\mathrm{a}} \text { accepted }\end{array}$ \\
\hline & PG Large > PG Small & $\begin{array}{l}\text { PG Large } \\
\text { PG Small }\end{array}$ & $<0.001$ & $<0.001$ & $\begin{array}{c}>99.9 \% \text { probability } \\
\mathrm{H}_{\mathrm{a}} \text { accepted }\end{array}$ \\
\hline Different & \multirow{2}{*}{ Melita $\neq$ Arborg } & $\begin{array}{l}\text { Melita Large } \\
\text { Arborg Large }\end{array}$ & $>=0.05$ & $>=0.05$ & $\mathrm{H}_{\mathrm{a}}$ rejected \\
\hline $\begin{array}{l}\text { Locations, } \\
\text { Same Variety }\end{array}$ & & $\begin{array}{l}\text { Melita Small } \\
\text { Arborg Small }\end{array}$ & $>=0.05$ & $>=0.05$ & $\mathrm{H}_{\mathrm{a}}$ rejected \\
\hline \multirow{2}{*}{$\begin{array}{c}\text { Different } \\
\text { Variety, Same } \\
\text { Location }\end{array}$} & \multirow{2}{*}{ Bethune $\neq$ Prairie Grande } & $\begin{array}{l}\text { Melita Large } \\
\text { PG Large }\end{array}$ & $>=0.05$ & $>=0.05$ & $\mathrm{H}_{\mathrm{a}}$ rejected \\
\hline & & $\begin{array}{l}\text { Melita Small } \\
\text { PG Small }\end{array}$ & $<0.05$ & $>=0.05$ & Inconclusive \\
\hline
\end{tabular}

From the results in Table 9, it can be observed that both CIC and NDSU results show the difference in the diameters produced from the small or large stem sources is statistically significant. These results contrast when comparing differences by variety or location. It appears that the stem size may have a greater influence on technical fiber diameters than variety or location when the preparation processes were the same.

Hence, it is expected that when manufacturing composites with smaller diameter fibers, they would facilitate better stress transfer from fiber to matrix compared to the otherwise identical larger diameter fibers, [20]. It would be advantageous to the bio-composite industries because they would be able to select fields that have a narrow and preferential range of stem diameter, thus producing smaller, stronger fibers and composites.

\subsection{Overall Discussion}

The tensile properties of flax fiber varies along the length of the stem of flax plants and the best tensile performance occurs in the middle portion of the stem [24]. In addition, the fiber diameter decreases from the bottom to the top of the stem [23]. This suggests that the variations found within each sample in this study could be a result of scattering induced by using fibers from the entire stem. However, the entire portion of the stems were used for all the samples, and the statistically significant differences found between samples is unlikely to be caused by in-stem locational differences.

It was shown that the decrease in diameter correlates with the increase in tensile strength; however, the actual cause of the mechanical performance was attributed to the biochemical differences, rather than morphological ones $[7,24,25]$. Charlet et al. $[24,25]$ explained that the middle fiber cell walls exhibit the highest contents of both cellulose and non-cellulosic polymers which favors the load transfer from one microfibril to another. When fibers with similar diameters from different sections of the stem were compared, the mechanical differences were still present. The difference in biochemical constituents was suggested to be due to the differences in growing conditions. The bottom and top fibers are usually developed in a less desirable or interrupted growing conditions. The hypothesis of this study was that the differences in stem geometry may have influence on fiber performance. Because smaller stems may have to rely more heavily on fiber reinforcement to resist external loading conditions. The same principle may explain within-stem fiber differences; fibers at the stem from 
bottoms, middles and tops are exposed to different loading conditions and different stem geometry, which results in a difference in fiber morphology. On that basis, differences in biochemical constituents may also be present between large and small stem fibers, which may result in differences in mechanical performance of the same.

\section{Conclusions}

This study proposed that in linseed flax, the stem diameter could be correlated to the mechanical performance of the extracted fibers. This is because the smaller stems are needed to rely more on fibers for reinforcement to withstand bending forces whereas larger stalk plants would be able to capitalize on their stiffer geometry (thicker stems and corresponding greater cross-sectional area). Ultimate tensile strength, Young's modulus, and failure strain were selected to evaluate this hypothesis with the expected results of tensile strength and Young's modulus being greater with smaller stem's fiber than larger stem's and no correlation to occur with the failure strain. Welch's $t$-tests for tensile strength showed a statistically significant negative correlation with stem diameter. For Young's modulus, the results were inconclusive. One facility showed negative correlation with stem diameter and this was supported by the second facility in one of the three cases. Failure strain in relation to stem diameter was found to be significant in one of the three cases; however, a trend was not present at either facility. No significance was found for location or variety.

In addition to the mechanical evaluation, the technical fiber diameter was also compared and a statistically significant positive correlation was found with stem diameter. This correlation is useful for composites as smaller fiber diameters facilitate better stress transfer from fiber to matrix than otherwise identical larger fibers.

This study also investigated if correlation exists between ultimate tensile strength, Young's modulus, failure strain, or fiber diameter and different varieties of linseed flax (Bethune and Prairie Grande) or growing locations (Melita, Manitoba and Arborg, Manitoba) when stem diameter range was controlled. No statistically significant correlations were found.

Based on the strong correlations relating stem diameter to ultimate tensile strength and fiber diameter, the weak/potential correlation between stem diameter and Young's modulus, and the lack of correlations between location and varieties, it is recommended that stronger consideration of stem diameter be used when evaluating differences in performance between linseed flax samples. In this study, a difference in performance was found between 'small' and 'large' stems that were separated by a modest $0.15 \mathrm{~mm}$ range. Therefore, it is indicated that large variations in stem diameters within samples could account for large standard deviations during fiber testing.

Stalk diameter is relatively easy to measure, and it is plausible that methods could be developed to measure diameter quickly and non-destructively in the field. The Canadian flax industry primarily grows linseed flax with a potential of 500,000 to 1,000,000 tons of salvageable straw per year [37]. Developing stem diameter measurements as a predictive tool for the performance of the fibers would allow industry to anticipate the value of a field before it is harvested, leading to performance-based grading. Industries that processes flax straw into fiber could use stem diameter to anticipate the fineness of their fiber outputs, as well as energy inputs required for processing, which could be used to predict the production costs as well as the market and value for the material.

Acknowledgments: The authors would like to acknowledge the contributions of the FibreCITY team (Jennifer Bell, Shuhan Liu, Lin-P'ing Choo-Smith, Frank Wheeler and Diogenes Vedoy) who participated in the acquisition, processing, treating, and testing of the samples under the guidance of the authors M. A. and S. D. Funding received by the CIC from Manitoba Agriculture and Research Manitoba contributed to field trials that produced the flax straw materials used in this study. Additional funding to CIC from Agriculture and Agri-Food Canada, Manitoba Agriculture, Western Economic Diversification Canada and the Province of Manitoba supported the development of test procedures as well as the laboratory work to generate the study data. Funding received by NDSU for this study was provided by the Composites Innovation Center (CIC), Winnipeg, Canada, and the North Dakota Department of Commerce-Center for Biobased Materials Science and Technology (BiMat). 
Author Contributions: Mercedes Alcock, Shawna DuCharme and Chad Ulven conceived and designed the samples for the experiments. Shawna DuCharme managed the project at CIC and Chad Ulven managed the project at NDSU. Mercedes Alcock and Shawna DuCharme coordinated and/or participated in acquiring the materials, including drying, measuring, analysis of dimensions, sorting, de-seeding, retting and decorticating. Mercedes Alcock performed the experiments at CIC and built analysis tools to process the data at the CIC. Shabbir Ahmed performed the experiments at NDSU. Mercedes Alcock and Shabbir Ahmed analyzed the data from CIC and NDSU using statistical methods. Mercedes Alcock and Shabbir Ahmed wrote the paper. Shawna DuCharme and Chad Ulven edited the paper.

Conflicts of Interest: The authors declare no conflict of interest. The founding sponsors had no role in the design of the study; in the collection, analyses, or interpretation of data; in the writing of the manuscript, and in the decision to publish the results.

\section{References}

1. Mueller, D.H.; Krobjilowski, A. New discovery in the properties of composites reinforced with natural fibers. J. Ind. Text. 2003, 33, 111-130. [CrossRef]

2. Pandey, J.K.; Ahn, S.H.; Lee, C.S.; Mohanty, A.K.; Misra, M. Recent advances in the application of natural fiber based composites. Macromol. Mater. Eng. 2010, 295, 975-989. [CrossRef]

3. Fuqua, M.A.; Huo, S.; Ulven, C.A. Natural fiber reinforced composites. Polym. Rev. 2012, 52, $259-320$. [CrossRef]

4. Diederichsen, A.; Richards, K. Cultivated flax and the genus Linum L. Taxonomy and the germplasm conservation. In Flax: The Genus Linum; Muir, D.A., Westcott, N.D., Eds.; CRC Press: Boca Raton, FL, USA, 2003; pp. 22-54; ISBN 978-0-415-30807-6.

5. Batra, S.K. Other long vegetable fibers. In Handbook of Fiber Chemistry, 3rd ed.; Lewin, M., Ed.; CRC Press: Boca Raton, FL, USA, 2006; ISBN 978-0-8247-2565-5.

6. Mukherjee, P.; Satyanarayana, K. An empirical evaluation of structure-property relationships in natural fibers and their fracture behaviour. J. Mater. Sci. 1986, 21, 4162-4168. [CrossRef]

7. Morvan, C.; Andème-Onzighi, C.; Girault, R.; Himmelsbach, D.S.; Driouich, A.; Akin, D. Building flax fibers: More than one brick in the walls. Plant Physiol. Biochem. 2003, 41, 935-944. [CrossRef]

8. Norton, A.J.; Bennett, S.J.; Hughes, M.; Dimmock, J.P.R.E.; Wrigth, D.; Newman, G.; Harris, I.M.; Edwards-Jones, G. Determining the physical properties of flax fibre for industrial applications: The influence of agronomic practice. Ann. Appl. Biol. 2006, 149, 15-25. [CrossRef]

9. Newman, R. Development of non-wood natural-fibre composites. In Properties and Performance of Natural-Fibre Composites, 1st ed.; Pickering, K.L., Ed.; Woodhead Publishing Limited: Cambridge, UK, 2008; pp. 193-208; ISBN 978-1-84569-267-4.

10. Romhany, G.; Karger-Kocsis, J.; Czigany, T. Tensile fracture and failure behavior of technical flax fibers. J. Appl. Polym. Sci. 2003, 90, 3638-3645. [CrossRef]

11. Gibson, L.J. The hierarchical structure and mechanics of plant materials. J. R. Soc. Interface 2012, 9, $2749-2766$. [CrossRef] [PubMed]

12. Baley, C.; Le Duigou, A.; Bourmaud, A.; Davies, P. Influence of drying on the mechanical behaviour of flax fibers and their unidirectional composites. Compos. Part A Appl. Sci. Manuf. 2012, 43, 1226-1233. [CrossRef]

13. Nishino, T. Natural fiber sources. In Green Composites, Polymer Composites and the Environment, 1st ed.; Baille, C., Ed.; Woodhead Publishing Limited: Cambridge, UK, 2004; pp. 49-80; ISBN 1-85573-739-6.

14. Lefeuvre, A.; Bournard, A.; Morvan, C.; Baley, C. Elementary flax fiber tensile properties: Correlation between stress-strain behaviour and fiber composition. Ind. Crop. Prod. 2014, 52, 762-769. [CrossRef]

15. Baley, C. Analysis of the flax fibers tensile behaviour and analysis of the tensile stiffness increase. Compos. Part A Appl. Sci. Manuf. 2002, 33, 939-948. [CrossRef]

16. Shah, D.U.; Nag, R.K.; Clifford, M.J. Why do we observe significant differences between measured and 'back-calculated' properties of natural fibers? Cellulose 2016, 23, 1481-1490. [CrossRef]

17. Andersons, J.; Porike, E.; Spārniňš, E. Ultimate strain and deformability of elementary flax fibers. J. Strain Anal. Eng. Des. 2011, 46, 428-435. [CrossRef]

18. Rowell, R.M. Natural fibres: Types and properties. In Properties and Performance of Natural-Fibre Composites, 1st ed.; Pickering, K.L., Ed.; Woodhead Publishing Limited: Cambridge, UK, 2008; pp. 3-66; ISBN 978-1-84569-267-4. 
19. Lefeuvre, A.; Bournard, A.; Lebrun, L.; Morvan, C.; Baley, C. A study of the yearly reproducibility of flax fiber tensile properties. Ind. Crop. Prod. 2013, 50, 400-407. [CrossRef]

20. Staiger, M.P.; Tucker, N. Natural fibre composites in structural applications. In Properties and Performance of Natural-Fibre Composites, 1st ed.; Pickering, K.L., Ed.; Woodhead Publishing Limited: Cambridge, UK, 2008; pp. 270-300; ISBN 978-1-84569-267-4.

21. Bourmaud, A.; Morvan, C.; Bouali, A.; Placet, V.; Perré, P.; Baley, C. Relationships between micro-fibrillar angle, mechanical properties and biochemical composition of flax fibres. Ind. Crop. Prod. 2013, 44, 343-351. [CrossRef]

22. Bourmaud, A.; Gibaud, M.; Lefeuvre, A.; Morvan, C.; Baley, C. Influence of the morphology characters of the stem on the lodging resistance of Marylin flax. Ind. Crop. Prod. 2015, 66, 27-37. [CrossRef]

23. Bourmaud, A.; Gibaud, M.; Lefeuvre, A.; Morvan, C.; Baley, C. Influence of Stem Morphology and Fibres Stiffness on the Loading Stability of Flax. In Natural Fibres: Advances in Science and Technology towards Industrial Applications, 1st ed.; Fangueiro, R., Rana, S., Eds.; Springer: Dordrecht, The Netherlands, 2016; Volume 12, pp. 49-59; ISBN 978-94-017-7515-1.

24. Charlet, K.; Baley, C.; Morvan, C.; Jernot, J.P.; Gomina, M.; Bréard, J. Characteristics of Hermès flax fibres as a function of their location in the stem and properties of the derived unidirectional composites. Compos. Part A Appl. Sci. Manuf. 2007, 38, 1912-1921. [CrossRef]

25. Charlet, K.; Jernot, J.P.; Gomina, M.; Bréard, J.; Morvan, C.; Baley, C. Influence of Agatha flax fibre location in a stem on its mechanical, chemical and morphological properties. Compos. Sci. Technol. 2009, 69, 1399-1403. [CrossRef]

26. Yan, L.; Chouw, N.; Jayaraman, K. Flax fibre and its composites-A review. Compos. Part B Eng. 2014, 56, 296-317. [CrossRef]

27. Charlet, K.; Jernot, J.P.; Bréard, J.; Gomina, M. Scattering of morphological and mechanical properties of flax fibres. Ind. Crop. Prod. 2010, 32, 220-224. [CrossRef]

28. Bourmaud, A.; Gibaud, M.; Baley, C. Impact of seeding rate on flax stem stability and the mechanical properties of elementary fibres. Ind. Crop. Prod. 2016, 80, 17-25. [CrossRef]

29. Gibaud, M.; Bourmaud, A.; Baley, C. Understanding the lodging stability of green flax stems; The importance of morphology and fibre stiffness. Biosyst. Eng. 2015, 137, 9-21. [CrossRef]

30. Zeng, X.; Moone, S.J.; Sturrock, C.J. Assessing the effect of fibre extraction processes on the strength of flax fibre reinforcement. Compos. Part A Appl. Sci. Manuf. 2015, 70, 1-7. [CrossRef]

31. Flax Council of Canada. Chapter 2: Seed and Seeding Practices. In Growing FLAX Production Management $\mathcal{E}$ Diagnostic Guide, 5th ed.; Flax Council of Canada: Winnipeg, MB, Canada, 2016; pp. 9-12.

32. Bell, J. The Effect of Maturity on the Tensile Strength of Technical Flax Fibers. Bachelor's Thesis, University of Manitoba, Winnipeg, MB, Canada, 2015.

33. Miller, J.H.; Burton, M.G.; Manning, T. A statistical study of the relations between flax fiber numbers and diameters and sizes of stems. J. Agric. Res. 1945, 70, 269-281.

34. SeCan: Canada's Seed Partner: Flax Varieties. Available online: https://www.secan.com/en/?category= Home\&title=SeCan\%20West\&args[page]=select_cropkind\&args[group_code]=oilseeds\&args[cropkind] =FLAX\&args[block_name]=varietysearch\&args[region]=WEST (accessed on 3 November 2017).

35. Thomason, J.L.; Carruthers, J.; Kelly, J.; Johnson, G. Fiber cross-section determination and variability in sisal and flax and its effects on fiber performance characterisation. Compos. Sci. Technol. 2011, 71, 1008-1015. [CrossRef]

36. ASTM International. ASTM C1557-14 Standard Test Method for Tensile Strength and Young's Modulus of Fibers; ASTM International: West Conshohocken, PA, USA, 2014.

37. Flax Council of Canada. Chapter 12: Flax Straw and Fibre Past and Present Uses. In Growing FLAX Production Management $\mathcal{E}$ Diagnostic Guide, 5th ed.; Flax Council of Canada: Winnipeg, MB, Canada, 2016; pp. 54-61.

(C) 2018 by the authors. Licensee MDPI, Basel, Switzerland. This article is an open access article distributed under the terms and conditions of the Creative Commons Attribution (CC BY) license (http:/ / creativecommons.org/licenses/by/4.0/). 